\title{
The Saving-Inflation Puzzle: Explaining their Relationship in Ethiopia
}

\author{
Abate Yesigat Taye \\ Lecturer, Department of Economics, Hawassa University
}

\begin{abstract}
The objective of this study is to show the effect of inflation on savings in a Small open economy Ethiopia for the period 1974-2014 using autoregressive distributed lag (ARDL) and ECM. The result of Cointegration test, using ARDL bounds testing approach, indicates the existence of long run relationship among the variables entered in the regression model and between inflation and national saving .To explores the direction of causality between inflation and National saving Granger Causality test has been employed. The direction of causation test indicated the existence of unidirectional causality running from inflation to saving, but saving does not granger causes inflation. Further, the long run estimation result shows that there is significant positive effect of inflation on national saving in the long run and insignificant negative effect in the short run.
\end{abstract}

Keywords - ARDL, Ethiopia, Inflation, Saving

\section{INTRODUCTION}

National Saving in macroeconomic theory is defined as the combination of public and private saving rates of a nation. It plays very important role in economic growth and development. Low national saving is one of the most series obstacles to achieving higher and more sustainable economic growth. Positive change in saving rate promotes the growth rate. For that reason saving is one of the factors for economic growth, accumulated saving is the source for capital stock which leads to increase investment, output and more employment (Solow, 1956). Saving rates around the world vary widely .For instance, on average for the past three decades East Asia saves more than $40 \%$ of gross disposable income while the average for SSA is $20 \%$. There are many presumptions towards explaining the regional imbalances, but the theoretical dominating ones are income streams, fiscal policy, preferences, or demographics and vulnerability to different shocks. When we see the Ethiopian case, even though, robust and broad based economic growth places Ethiopia among the top performing African and other developing Asian countries ,the economy is characterized by a low domestic saving rate, vulnerability to shocks, negative trade balance and others. For instance, external vulnerabilities have increased as exports of goods and services slowed significantly, while imports continued growing fast. A sharp widening of the current account deficit to an estimate 12.8 percent of GDP in 2014/15, low saving habit to finance domestic investment (saving gap), in 2014/15 gross capital formation (Investment) was about $40.3 \%$ of GDP, while the gross domestic saving was only $22.5 \%$ for the same fiscal year (NBE, 2014/15). These structural bottlenecks to development are highly interlinked and one re-enforces the other. One of the most pressing issues which affect macroeconomic stability in recently in Ethiopia is inflation. Though, the Ethiopian economy was known for its low inflation historically. However, following 2003 period inflation began to appear as a major problem especially following the government's move towards less conservative monetary and fiscal policy and state activism in the economy. For instance, during 2004-2010 annual inflation average was $15.4 \%$ for Ethiopia, which is higher than the Sub Saharan Africa average of 8.8\% for the same period (IMF, 2011).

One major problem facing Ethiopia in achieving accelerated growth and development is low level of capital formation due to low level of saving. Inadequate capital formation to undertake the real investment has adversely affected the output level of the economy. Lack of adequate capital formation results from nonavailability of credit to adding to existing ones. Therefore, national savings in Ethiopia is a very critical and reliable factor in capital formation process. Capital formation, whether financed from internal domestic saving or from external sources, requires the mobilization of economic surpluses. The relationship between inflation and saving becomes issue of debate among the macroeconomists, policy makers and central monetary authorities. The argument is that whether inflation is necessary for economic growth or it is detrimental to growth through saving and investment. Theoretically, there is controversy on the relationship between inflation and saving. Mundell (1963) and Tobin (1965) have successfully explained the effect of inflation on economic growth and saving based on neo-classical growth theory. They believe increased nominal interest caused by 
inflation will make people option to save and investment instead of consumption. This will result in increasing capital accumulation which will stimulate saving and economic growth. Mundell (1963) and Tobin (1965) depict a positive relationship between inflation and saving. Contrary to the conclusion of the Mundell-Tobin Effect, Stockman (1981) develops a long-run equilibrium growth model with assumption of "cash-in-advance constraint". In the model of Mundell (1963) and Tobin (1965), real money balances and investment are substitution. But in the model of Stockman (1981), the two variables' relationship is complement, accounting for a negative relationship between the steady-state level of output and the inflation rate. Stockman's insight is prompted by the fact that firms put up some cash in financing their investment projects. Sometimes the cash is directly part of the financing package, whereas other times, banks require compensating balances. Stockman models this cash investment as a cash-in-advance restriction on both consumption and capital purchases. Since inflation erodes the purchasing power of money balances, people reduce their purchases of both cash goods and capital when the inflation rate rises. Correspondingly, the steady-state level of output falls in response to an increase in the inflation rate (Malla, 1997). If the incomes are not indexed, unanticipated inflation will cause unanticipated cuts in the real income and hence decreased the saving rates. Also, high inflation can increase the opportunity cost of holding money and increase the rewards for the search activities in shopping wasting real resources and thereby reducing savings (Miller and Benjamin, 2008). As against this, another theory proposes that if the real income is correctly anticipated either by indexation or wage inflation, unanticipated inflation will increase the saving rate. Inflation is a good proxy for macroeconomic uncertainty. Higher uncertainty/higher inflation induces people to save a larger portion of their money for precautionary motives. Sidrauski (1967) in a general equilibrium framework found that money remained neutral in the time steady state. So, inflation has no impact on savings in the long run. Like the contradicting theoretical views different empirical studies both in developed and developing countries shows different results. Some studies finding a negligible effect of inflation on saving (e.g. Chari et al., 1996, Celik and Kayali, 2009), some findings a negative effect (Chopra, 1988; Fischer, 1993; Romer, 1999; Ahimad and Muhamood, 2013; Osundinak and OsundinaJ, 2014; Gylfason and Herbertsson, 2001) and some studies providing an evidence of positive effect (Dholakia, 1995; Mallik and Chowdhury, 2001; Mundel, 1963 and Tobin, 1965). Despite this plethora of studies both for developing and developed countries, the literature on the relationship between saving and inflation in Ethiopia is scanty and focused on the determinants of saving. There is also lack of consensus in the findings as to the effect of inflation on saving. For instance, (Yohannes, 2014) studied the macroeconomic determinants of gross national saving in Ethiopia using time series annual data form 1970-2011 by using ARDL approach and found statistically insignificant effect of inflation on gross national saving in Ethiopia both in long run and short run. (Haile, 2013) analyzed the macroeconomic determinants of gross national saving in Ethiopia using time series annual data form 1971-2011, and conduct the study by ARDL bounds testing approach and ECM model. He found that inflation affects national saving significantly and negatively in the long run and insignificant effect in the short run. (Feyera, 2015) also analyzed the link between inflation rate, national saving rate and per capita income growth rate in Ethiopia using co-integrated VAR approach for the period 1980 - 2014 in Ethiopia. The result shows that inflation rate exert positive and significant impact on gross national saving rate in the long run and negative and insignificant effect on national saving in the short run. Thus, the empirical literature in Ethiopia case also shows the existence of inconclusive result regarding the effect of inflation on saving. Thus, this research focused on examining the causal relationship between national savings and inflation in Ethiopia that is to put light on how inflation affects national saving. Hence, the motivation is to fill the indicated gap in the context of Ethiopia

\subsection{Model specification}

\section{METHODOLOGY}

Many empirical literatures in the area of saving show a number of factors that can determine domestic saving behavior both in developed and developing countries. However, taking into account data constraints, this study tries to examine the effect of inflation on national saving by including the following control variables in the estimable saving function model:

$$
\begin{gathered}
\mathrm{GNS}=\beta 0+\beta 1 \mathrm{gPCI}+\beta 2 \mathrm{IR}+\beta 3 \mathrm{INF}+\beta 4 \mathrm{BD}+ \\
(+) \quad(+/-) \quad(+/-) \quad(-) \quad(-)
\end{gathered}
$$

\section{Variables description}

Gross National saving (GNS): - It is derived by deducting financial consumption expenditure from gross national disposable income, and consists of personal saving, business saving and government savings.

Inflation (INF): - which is a general rise in prices measured against a standard level of purchasing power. There are many measures of inflation depending on the specific circumstances. The consumer price index (CPI) measures the percentage change through time in the cost of purchasing a constant basket of goods and 
service representing the average pattern of purchases made by a particular population group in a specific time period. Inflation is expected to have positive or negative impact on saving.

Per capita income growth rate (PCI): - Growth rate of GDP per total population of the country. GDP is the sum of gross value added by all resident producers in the economy plus any product taxes and minus any subsidies not included in the value of products. It is calculated without making deduction for depreciation of fabricated assets or for depletion and degradation of natural resources. It is expected that per capita income has positive impact savings.

Interest Rate (IR): - Theoretically, interest rate changes are subject to potentially offsetting positive substitution and negative income effects. The substitution effect is that a higher interest rate raises the current price of consumption relative to future price. This reduces current consumption and increase saving. The income effect is that if the households are net lenders, an increase in interest rate will increase lifetime income, and so increase present consumption by decreasing saving. In this case, if the substitution effects out way the income effect, aggregate saving will rise and vice.

Current account deficit (CAD): - which is measured as exports minus imports, represents how the external sector affect gross national saving ratio. An increase in current account deficit (foreign saving) is associated by a partial decline in domestic saving, as foreign saving may tend to act as a substitute to domestic saving. Thus, the expected effect of current account deficit on domestic saving is negative.

Budget Deficit (BD): - which is measured as the Budget deficit is the difference between government revenue and government expenditure which turns out to be negative for Ethiopia. In this study, budget deficit is employed as an indicator for the fiscal policy of government which has a direct impact on gross national saving by reducing public saving given that the Rechardian hypothesis does not hold.

\subsection{Data type and source}

The study used annual time series secondary data collected from Ministry of Finance and Economic Development (MoFED), National Bank of Ethiopia (NBE), Central statistic agency (CSA), and (EEA -CD room). The study use annual time series secondary data covering the period from 1974 to 2014.

\subsection{Methods of Data Analysis and Estimation Techniques}

In this study both simple descriptive and econometric methods of data analysis were used. In order to examine the existence of co-integration between inflation and domestic saving in Ethiopia bounds testing approach was used. This method of testing Cointegration is more superior to VAR and Engle and Granger, in case of the existence of different order of integration among the variables and when the sample size is small. Thus, in this study the ARDL approach was developed by Pesaran and Shin (1999) and Pesaran et al. (2001) and is used in the current study because of its many advantages. It is efficient estimator in small sample studies and allows for the use of different lags and been appropriate when the unit root properties are not known.

\section{DATA ANALYSES AND INTERPRETATIONS}

The descriptive method is used to assess the trends of inflation with time, and the cross plot of price level with saving to see their relationship graphically since 1974 up to 2014, whereas the time series econometric technique is used to estimate the long run and short run relationship between inflation and saving and their direction of causality will be determined using ARDL, ECM and Granger causality test.

\subsection{Trend of Gross National Saving Ratio and Gross Fixed Capital Formation as share of GDP}

Even though gross national saving is unable to cover all the investment requirements at times we cannot ignore the role it has played in financing gross fixed capital. As it can be seen from the figure below figure, both gross national saving ratio and gross fixed capital formation as share of GDP fluctuate in the same direction. That is Savings and investments show similar growth patterns even though the direction of causality between the two cannot be ascertained as can be seen from the above graph. Bridging the gap is, however, still a big challenge that Ethiopia has to face in the coming years. Recent performances show that saving is indeed growing at a slightly higher rate than investment signaling hope for catching up. 
Figure 1. Trend of Gross National Saving ratio and Gross Fixed Capital Formation as share of

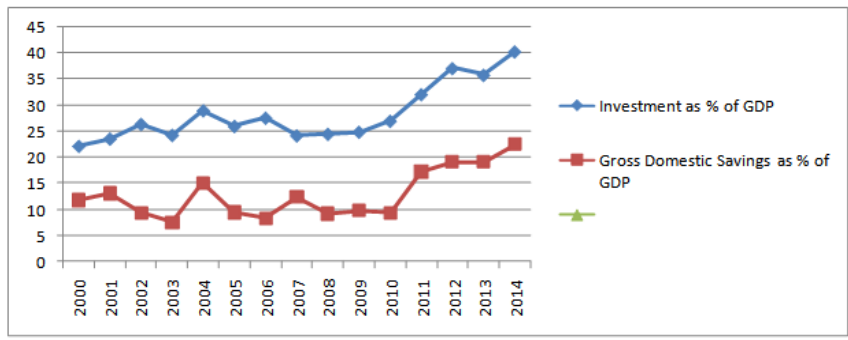

Source: Own computation based on NBE data, 2014/15.

\subsection{Trend of Inflation and Gross National Saving}

As stated in the introduction and statement of the problem part there is inconclusive relationship between inflation and national saving as both theoretical and empirical result reveled. Looking the trend of inflation and saving in figure 2 below supports the theoretical and empirical literature that explained positive relationship between the two in Ethiopian case.

Figure 2: Trends of inflation and Gross National Saving with time

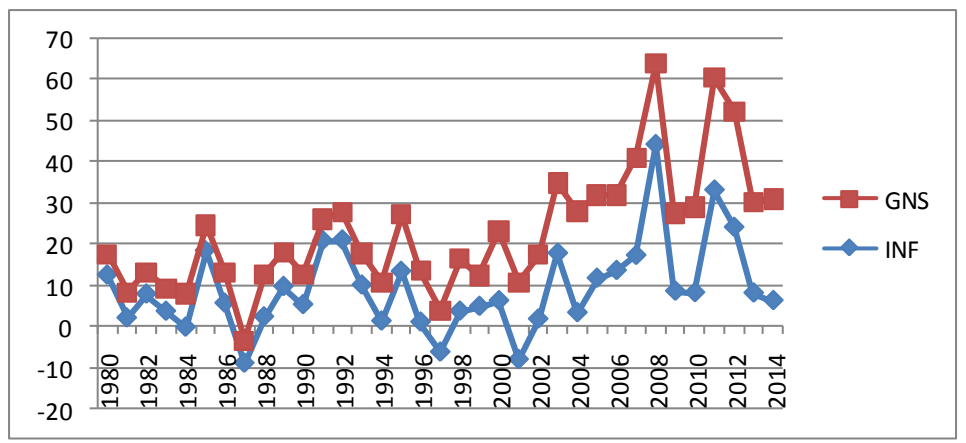

Furthermore, the cross plots of inflation against gross national saving revealed that an increase in inflation in the economy leads to an increase in saving. As can be seen from figure 3 below, as inflation o increases (when we move from the origin to the right) gross national saving (GNS) increases. This positive relationship between inflation and saving can be explained by Mundell (1963) and Tobin (1965) neo-classical growth theory. That is according to them the increased inflation leads to increased nominal interest, which then will make people option to save and investment instead of consumption. This will result in increasing capital accumulation which will stimulate saving and economic growth.

Figure 3: Cross plot of gross national saving on inflation

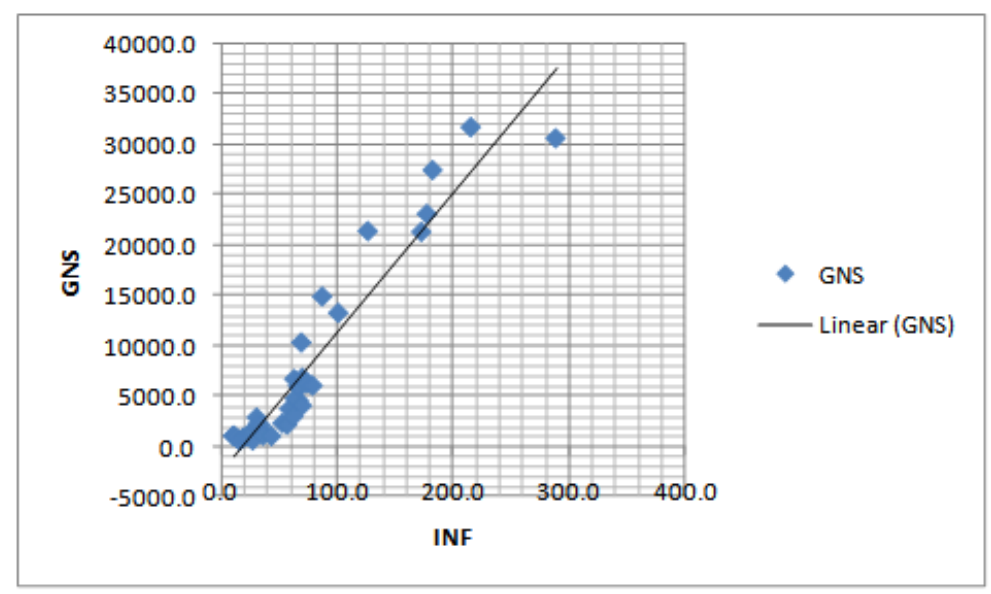

Source: Own computation based on MoFED and NBE data, 2015. 


\subsection{Econometric Estimation Results and Discussions}

In this part of the analysis, the time series econometric method was employed to estimate the relationship and the direction of causality between inflation and saving. Eviews 8 econometric software was used for all econometric method of analysis.

\subsubsection{The Unit root test for stationary}

The formal investigation is carried out by examining the stochastic properties of the variables by using Unit Root test to taste the stationary of the variables. In this context, the widely used technique is Augmented Dickey Fuller (ADF) test is conducted to detect stationary of the variables. Table 1 below shows values of the estimates, and most of the variables were found to have unit root problem (non-stationary), except CPI, which is stationary at level. Thus it has been treated by taking the first difference of the level data, which turned the data to be stationary.

Table 1: Results of Unit Root Test (ADF)

\begin{tabular}{|l|l|l|l|}
\hline $\begin{array}{l}\text { Variables at level and } 1^{\text {st }} \\
\text { difference at which } \\
\text { stationarity detected }\end{array}$ & With constant only & $\begin{array}{l}\text { With constant } \\
\text { \&trend }\end{array}$ & $\begin{array}{l}\text { Order of } \\
\text { integration }\end{array}$ \\
\hline LGNS & $-4.524113^{* * *}$ & $-4.718633^{* * * *}$ & \\
\hline$\Delta$ GNS & $-5.564740^{* * *}$ & $-5.697409^{* * *}$ & 1 \\
\hline LPCI & $-4.927529^{* * *}$ & -2.134375 & 0 \\
\hline IR & -0.818186 & -2.139678 & \\
\hline$\Delta \mathrm{IR}$ & $-4.786337^{* * *}$ & $-13.13775^{* * *}$ & 1 \\
\hline LBD & -0.236686 & -1.823547 & \\
\hline$\Delta \mathrm{LBD}$ & $-10.20216^{* * *}$ & $-10.19766^{* * *}$ & 1 \\
\hline LCAD & -0.665852 & -1.154337 & \\
\hline$\Delta \mathrm{LCAD}$ & $-6.160036^{* * * *}$ & $-6.751096^{* * * *}$ & 1 \\
\hline LINF & $-6.439147^{* * *}$ & $-6.362315^{* * *}$ & 1 \\
\hline & & & \\
\hline
\end{tabular}

Note: ***, **, * represents Significant at 1\%, 5\%, $10 \%$ respectively

Source: Owen computation based on the given data

\subsubsection{Bounds Tests for Co-integration}

The first task in the ARDL approach to Co-integration is estimating the general ARDL model is laglength selection criteria. In this paper AIC is taken as a guide and optimum lag order of 2 is chosen for the ARDL model. So, a Schwarz-Bayesian criterion was taken as a guide and a maximum appropriate lag order of two was chosen in determining the conditional ARDL model. The Bound test for co-integration is run to check the joint significant of the coefficients in the specified conditional ARDL model. The Wald test is conducted for this equation by imposing restrictions on the estimated long run coefficients of all lagged level variables in equation 3.6 and the F-statistic found 14.917 as shown in Table 2. Since, the calculated F-static is greater than the upper bound critical value at $1 \%, 5 \%$ and $10 \%$ level of significance using both restricted intercept and no trend and using restricted intercept $\&$ trend. This implies that the null hypothesis of no Cointegration is rejected at $1 \%$ level of significance. Therefore, there is Cointegration among the variables used in this study.

Table 2: Bounds test for co integration analysis

\begin{tabular}{|c|c|c|c|c|}
\hline \multirow{3}{*}{$\begin{array}{l}\text { Test } \\
\text { Statistics }\end{array}$} & \multirow{3}{*}{$\begin{array}{l}\text { Calculated } \\
\text { F-statistic }\end{array}$} & \multicolumn{3}{|c|}{ Bound critical values } \\
\hline & & \multirow{2}{*}{$\begin{array}{l}\text { Statistically } \\
\text { significance } \\
\text { level }\end{array}$} & \multicolumn{2}{|c|}{ Based on Narayan value(2005 } \\
\hline & & & $\begin{array}{l}\text { Lower } \\
\text { bound } \mathrm{I}(0)\end{array}$ & $\begin{array}{l}\text { Upper bound } \\
\text { I(1) }\end{array}$ \\
\hline \multirow[t]{3}{*}{ F-statistic } & \multirow[t]{3}{*}{14.917} & $1 \%$ & 5.38 & 5.94 \\
\hline & & $5 \%$ & 4.058 & 4.334 \\
\hline & & $10 \%$ & 2.625 & 4.67 \\
\hline
\end{tabular}




\subsubsection{Long-rum Model Estimation}

After confirming the existence of the long-run relationship between variables, the next step in ARDL is to estimate the long-run coefficients. To this end, Schwarz-Bayesian criteria is chosen with two maximum lag order and found the ARDL (1, 0, 0,2,0, and 2) equation. The estimated long-run relationships between the variables are estimated and the estimated coefficients are reported in Table 3.

Table 3: ARDL Long-run model estimated

\begin{tabular}{|l|l|l|l|l|}
\hline Dependent Variable is LGNS & \multicolumn{4}{l|}{} \\
\hline Variable & Coefficients & Standard Error & T-Ratio & Prob \\
\hline LPCI & 0.16612 & 0.066633 & 2.4931 & 0.022 \\
\hline LINF & 0.42296 & 0.24438 & 1.7308 & 0.096 \\
\hline IR & -0.70253 & 0.06357 & -1.051 & 0.304 \\
\hline LCAD & 0.36608 & 0.10298 & 3.5548 & 0.002 \\
\hline LBD & -0.03745 & 0.28247 & -1.3258 & 0.197 \\
\hline Constant & 2.0383 & 6.4577 & 15.1002 & 2.192 \\
\hline
\end{tabular}

The long run regression result in the above table indicated that per capital income, inflation and current account deficit are found statistically significant determinants of national saving in the long run at different level of significance. The impact of inflation rate on gross national saving rate is positive and significant. When inflation rate increases national saving rate also increases. The result shows that 1 percent point increase in inflation rate increases gross national saving rate by 0.42 percent points in the long run in the country. The result supports the neoclassical economists such as Tobin's (1965) and Mundell (1963) was the first to articulate a mechanism relating inflation and output growth and saving. According to him, an increase in inflation immediately reduces people's wealth. To accumulate the desired wealth, people save more, thus driving down the real interest rate. Greater saving means greater capital accumulation and thus faster output growth. According to him inflation affects saving positively.

\subsubsection{The Short Run Dynamic Modeling (Error Correction Model)}

After determining the long run relationship among the variables in the long run model and their long run coefficients, the next step is to determine the coefficients of the short run dynamics. The coefficient of short-run dynamics can be obtained by regressing the first difference of the dependent variable on its lag, the lagged error correction term, the first difference of all exogenous variables and their lags. The ECM shows the short run dynamics of the model which is consistent with the long run equilibrium of the model. The results of the ECM are reported in table 4 below.

Table 4: Estimation result of short run model.

\begin{tabular}{|l|l|l|l|l|}
\hline Dependent Variable is DGNS & Coefficie & Standard Error & T-Ratio & Prob \\
\hline Regressor & 0.21173 & 0.06040 & 3.009 & 0.005 \\
\hline DLCPI & -0.02082 & 0.00188 & -1.233 & 0.238 \\
\hline DLINF & 0.0024723 & $9.26 \mathrm{E}-04$ & 2.6696 & 0.013 \\
\hline DLCAD & -0.28328 & 0.13749 & -2.0604 & 0.049 \\
\hline DLBD & 0.75424 & 0.38075 & 1.9809 & 0.058 \\
\hline DIR & -0.6497 & 0.1438 & -2.1472 & 0.009 \\
\hline ECM(-1) & 0.71681 & R-Bar-Squared & 0.59 & \\
\hline R-squared & 0.046110 & F-Stat F(7.31) & 8.1248 & 0.000 \\
\hline SE of Regression & -0.0026316 & S.E of Dependent & 0.05921 & \\
\hline Mean of Dependent & 0.029584 & Equation Log-Likelihood & 82.0843 & \\
\hline Residual Sum of & 68.0843 & Schwartz Bavesian & 56.6212 & \\
\hline Akaiki info. & 2.012 & & & \\
\hline DW-statistic & & & & \\
\hline
\end{tabular}

The one year lagged error correction mechanism (ECM-1) included in the model to indicate how the time path matter to correct any error or deviation from long run equilibrium relation occurring in the previous period is correctly signed (negative) and significant at one percent level of significance. It points out that about 65 percent of the disequilibrium from the long run path will be corrected in one year. The magnitude of the coefficient also indicates that there is somewhat medium level of correction for divergence of saving function level from equilibrium. The robustness of the estimated long run and short run models are checked using some diagnostic tests. That is there is no error autocorrelation and heteroscedasticity, and the errors are normally. The long -run estimates stability has been also tested by utilizing cumulative sum of recursive residuals (CUMSUM) 
and cumulative sum of squares recursive residuals (CUMSUMSQ) tests which are recommended by (Pesaran and Shin, 1999, 2001)

\subsubsection{Granger Causality Test between Gross National Saving and Inflation}

Granger causality test provides important information of the causal direction between the variables and knowing the direction of causality helps for long-run and short run analysis between the variables.

Table 5: Pairwise Granger Causality Tests between GNS and INF Pairwise Granger Causality Tests

Null Hypothesis:

LOG(CPI) does not Granger Cause LOG(GNS) LOG(GNS) does not Granger Cause LOG(CPI)

$\begin{array}{ccc}\text { Obs } & \begin{array}{c}\text { F- } \\ \text { Statistic }\end{array} & \text { Prob. } \\ & & \\ 38 & 5.74295 & 0.0072 \\ & 0.83360 & 0.4434\end{array}$

The above table shows that the hypothesis that L (CPI) do not Granger caused L (GNS) is not rejected and L(GNS) does not Granger caused L(CPI) is rejected. This means that there is a unidirectional causality between inflation and national saving. That is, there is no Granger Causality from saving to inflation. Therefore there is unidirectional Granger causality from inflation to saving.

\section{CONCLUSIONS AND POLICY IMPLICATIONS}

This study tries to reveal the nature of saving -inflation relationship of Ethiopia by using the framework of ARDL and vector error correction(ECM) mechanism using annual data covering the period from 1974 to 2014 . All the variables are tested for unit roots by Augmented Ducky Fuller (ADF) test and the test result revealed the variables are stationary at their level and first difference. The result of co-integration test, using Bound test for co-integration approach, indicates the existence of long run relationships between the variables included in the model. The results of the ARDL and error correction models show the existence of positive long-run relationship between inflation and national saving in Ethiopia. Moreover, the Granger Causality Test found the unidirectional causal relationship running from inflation to saving..

Based on the findings of the study the following policy implications are suggested:

Since the result shows positive relationship between inflation and gross national savings in the long run and insignificant negative effect in the short run government should target appropriate optimal level of inflation rate to encourage national saving.

\section{ACKNOWLEDGEMENT}

The author would like to give gratitude to Hawassa University, Vice President for Research and Technology Transfer and Research Program Directorate offices for covering all the study costs.

\section{REFERNCE}

[1] Ahmad,K., and Mahmood, H. (2013). $\square$ Macroeconomic determinants of National savings Revisited: A small open economy of Pakistan. "world applied sciences journal 21(1),pp 49-57, National college of Administration and economics, Lahore, Pakistan

[2] Chari, V. V., Jones, L. E., and Manuelli, R. E. (1996), Inflation, Growth, and Financial Intermediation, Federal Reserve Bank of St. Louis, May/June 1996 Review

[3] Chopra, S. (1988), Inflation, Household Savings and Economic Growth, Ph. D. thesis, M. S. University of Baroda, India

[4] Dholakia, R. H. (1995). Expected Inflation and Short-Term Forecast of Growth Rate in India. IASSI Quarterly, Vol. 13, No. 4, pp. 44-67.

[5] Feyera G.(2015). The nexus between Inflation rate, Gross National Saving rate and per capita income growth rate in Ethiopia: the co-integrated VAR approach: MSc Thesis. Addis Ababa University

[6] Fischer, S. (1993), the Role of Macroeconomic Factors in Growth, NBER Working Paper Series, and Working Paper No. 4565

[7] Greene, W. H. (2000). Econometric Analysis, $4^{\text {th }}$ ed Prentice Hall International,Inc., USA

[8] Gokal and Hanif, G (2004), Relationship between Inflation and Economic Growth: Economic Department Reserve Bank of Fuji, Suva. 
[9] Gujarati, D.( 2003). Basic Econometrics, $4^{\text {th }}$ ed. The McGraw-Hill, Inc., New York.

[10] Gylfason, T. and Herbertsson, T. T. (2001). Does Inflation Matter for Growth? Japan and the World Economy, Volume 13, Number 4, December 2001 , pp. 405-428

[11] Haile A.(2013), "Determinants of domestic saving in Ethiopia: An autoregressive distributed lag (ARDL) bounds testing approach', Acadamic Journal of Economics and International Finance vol.5(6),pp248-257

[12] IMF(2011). World Economic outlook: World Economic and Financial Survey, Washington, DC: IMF.

[13] Malla, S. (1997) "Inflation and Economic Growth: Evidence from a Growth Equation", mimeo, Department of Economics, University of Hawai'I at Monoa.

[14] Mallik, G. and Chowdhury, A. (2001), Inflation and Economic Growth: Evidence from four South Asian Countries, Asia-Pacific Development Journal Vol. 8, No. 1, June 2001

[15] Miller, R. L. and Benjamin, D. K. (2008), The Economics of Macro Issues, Pearson Addison Wesley, Third Edition

[16] Mundell R. (1963).“ Inflation and Interest rate.” Journal of Political Economy, Vol. 71 No. 3, 280-283

[17] National Bank of Ethiopia Annual report (2014/15), Ethiopia

[18] Pesaran, M. H., Y.Shin \& Smith, R. J. (2001). Bounds Testing Approaches to the Analysis of Level Relationships. Journal of Applied Econometrics, 16, 289-326

[19] Solow, R.M. and T.W. Swan (1956). "Economic Growth and Capital Accumulation', Economic Record, 32, pp. 334-61.

[20] Yohannes G. (2014). An Empirical Time Series Analysis on the Determinants of Gross National Saving in Ethiopia: ARDL approach to Co-integration: MSc Thesis. Addis Ababa University 